\title{
Globalization and Income Inequality in Mexico, Indonesia, Nigeria, and Turkey: A
} Dynamic GMM Approach

\author{
Tolulope Temilola Osinubi ${ }^{1 \rtimes}$ \\ Philip Akanni Olomola² (iD
}

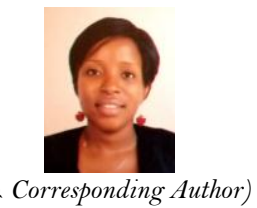

\begin{abstract}
This study examines the effect of globalisation on income inequality in Mexico, Indonesia, Nigeria, and Turkey between 1980 and 2018, using economic, social, political, and overall globalisation as proposed by Dreher., Gaston, and Martens (2008). The study employs a dynamic Generalised Method of Moments. Results show that economic globalisation significantly increases income inequality in Mexico and Turkey, but insignificantly reduces inequality in Indonesia and Nigeria. For social globalisation, inequality responds positively to it in all the MINT countries, except in Turkey. Political globalisation adds to income inequality in Mexico, but reduces inequality in Nigeria and Turkey. In Indonesia, political globalisation exerts insignificant positive effect on inequality. Overall globalisation increases income inequality in all the MINT countries, except in Indonesia. The study, therefore, concludes that the various dimensions of globalisation and overall globalisation are key drivers of income inequality in each of the MINT countries, except in some few cases.
\end{abstract}

Keywords: Economic globalization, Social globalization, Political globalization, Overall globalisation, Income inequality, Kuznets Hypothesis, Dynamic GMM.

JEL Classification: D31, F 15, F41, 010, 057

Citation | Tolulope Temilola Osinubi; Philip Akanni Olomola (2020). Globalization and Income Inequality in Mexico, Indonesia, Nigeria, and Turkey: A Dynamic Gmm Approach. Asian Journal of Economics and Empirical Research, 7(1): 91-104. History:

Received: 14 January 2020

Revised: 17 February 2020

Accepted: 28 March 202

Published: 11 May 2020

Licensed: This work is licensed under a Creative Commons

Attribution 3.0 License (cc) E E

Publisher: Asian Online Journal Publishing Group
Acknowledgement: Both authors contributed to the conception and design of the study.

Funding: This study received no specific financial support.

Competing Interests: The authors declare that they have no conflict of interests.

Transparency: The authors confirm that the manuscript is an honest, accurate, and transparent account of the study was reported; that no vital features of the study have been omitted; and that any discrepancies from the study as planned have been explained.

Ethical: This study follows all ethical practices during writing.

\section{Contents}

1. Introduction

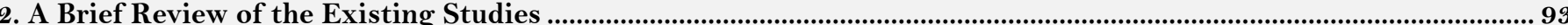
92

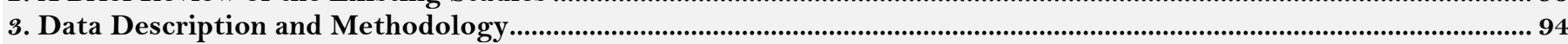

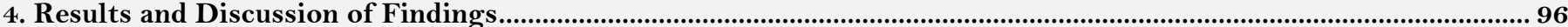

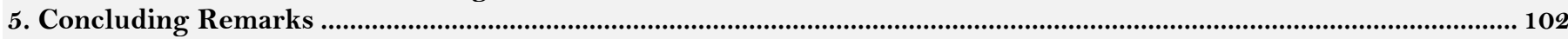

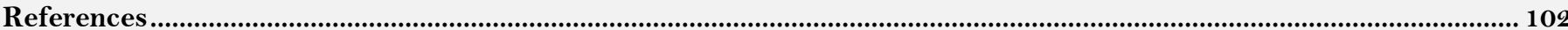




\section{Contribution of this paper to the literature}

The study contributes to the existing knowledge by examining the effect of globalisation, using different dimensions of globalisation- economic, social, and political globalisation, on income inequality in Mexico, Indonesia, Nigeria, and Turkey.

\section{Introduction}

Globalisation came into existence to promote wealth among all countries of the world with the United States being the leader after World War II. Then, the United States introduced the North American Free Trade Agreement (NAFTA) in 1993 to remove trade barriers and promote globalisation. Consequently, most countries started following suit in the $20^{\text {th }}$ century by investing in new forms of transportation (road, sea, rail, and air) and communication services (the use of internet and cell phones). This has helped in connecting billions of people around the globe. The process of globalisation, therefore, makes the whole world behaves as if it were a single market, with interdependent production, consuming similar goods, and responding to the same impulses. This means that the whole world is a global village and globalisation is meant to promote increased global output (Williamson, 2015)

Globalisation is an interaction of national economies, through trade and financial integration. However, globalisation has its own positive and negative sides. The positive sides are an increase in global output, exposure to new ideas and products, global awareness, economies of scale in production, increased specialization, competition and efficiency, improved social developments, and human welfare (Hassan, 2013). The negative sides include unemployment (Orga, 2012) economic insecurity and income inequality (Blinder, 2006; Krugman, 2008; Stiglitz, 2002; Summers, 2006).

Income inequality is seen as one of the responses to globalisation. This is affirmed by Williamson (2015) who argued that globalisation can influence income level and its distribution. Income distribution describes the degree or the extent to which the total gross domestic product of a country is distributed among its population or the smoothness with which income is distributed among members of society. It is perfectly equal if members of the population earn the same amount of money and perfectly unequal if only one person earns all the money in the society. And, income is said to be more evenly distributed in the developed countries than in the developing countries. Thus, income inequality is the extent to which incomes are unevenly distributed among the population of a given country (Rye, 2016).

According to Kuznets (1955) income inequality is high in the developing countries due to their lower level of average per capita income and it is expected to be reversed once they become more economically developed and richer. As expected, as an economy integrates with other economies, income inequality may reduce, that is, a negative association between globalisation and inequality. Evidence from the literature showed that globalisation alone cannot lower inequality but globalisation with the help of consistent and stable long-term economic policies (expansionary monetary and fiscal policies) to improve the level of growth, literacy level, government spending, reduce inflation and unemployment would go a long way in reducing inequality (Lee, 2014; Mihaylova, 2015). This implies that the effect of globalisation on income inequality is both direct and conditional.

The MINT countries, that is, Mexico, Indonesia, Nigeria, and Turkey, in recent times, have been observed to experience high level of income inequality even in the face of improved level of globalisation. These countries are popularized by Jim O'Neil of Goldman Sachs as emerging economies and are said to have their prospects and challenges (see Olomola and Osinubi (2018)). KOF (2018) reports that the overall globalisation indices are 73, 63, 56 , and 72 per cents, while the SWIID (2018) shows that the levels of income inequality are 45.8, 43, 40.1 and 39.8 per cents for Mexico, Indonesia, Nigeria, and Turkey, respectively. And, a country has high-income inequality if the GINI coefficient lies between 0.36 and 1.o. By implication, Mexico has the highest level of income inequality in all the MINT countries, while income inequality reduced from about 40 per cent in 2014 to about 39 per cent (SWIID, 2018) in Turkey but this does not take Turkey off of the list of the world's worst inequality countries.

Income inequality, as one of the responses to globalisation, has gained so much prominence in the literature, and globalisation is said to affect income distribution and its level. Previous studies (Atif, Srivastav, Sauytbekova, \& Arachchige, 2012; Baek \& Shi, 2016; Kratou \& Goaied, 2016) argue that globalisation can either reduce (in developed countries) or spur (in developing countries) income inequality. The question that comes to mind is that why do MINT countries still face the problem of income distribution despite their increased levels of globalisation and this calls for investigating the impact of globalisation on income inequality in each of the MINT countries.

This present study adds to the existing knowledge in the area of study because it uses different dimensions of globalisation (that is, economic, social, and political globalisation) and overall globalisation. Most studies (Baek \& Shi, 2016; Bukhari \& Munir, 2016; Jaumotte, Lall, \& Papageorgiou, 2013; Mihaylova, 2015) in the literature capture globalisation narrowly. Meanwhile, the concept of globalisation is wide as it includes economic, social, cultural, religious, and political dimensions. It has been argued that each of these components of globalisation affects economic agents differently. Then, using a generic measure of globalisation could mar the full impact of globalisation on the economy as well as on income inequality. For instance, these studies mentioned above used only one or two variables, that is, trade openness, foreign direct investment, financial integration, and technological globalisation as measures of globalisation and these are classified as economic globalisation according to Dreher (2006). In the real sense, the process of globalisation covers social and political dimensions asides the economic component of globalisation used by previous studies.

Explicitly for social globalisation, the idea is that improvement in information and communication technologies through telephone traffic, transfers as a percentage of GDP, international tourism, internet users, trade-in newspapers and books will create job opportunities which will help in reducing income inequality. While, political globalisation, as a result of the number of embassies in the country, international treaties, and membership in international organizations which in turn help to provide job opportunities in the economy, will help in inequality reduction. This paper is structured as follows: next to this introductory aspect is the brief review of the existing studies as shown in Section 2. Section 3 handles the data description and methodology employed. Section 4 
provides the empirical results with the discussion of findings. The paper ends with concluding remarks in Section 5 .

\section{A Brief Review of the Existing Studies}

In recent times, rising inequality has been a major concern of development and there are many studies on globalisation-inequality nexus. Looking at the relationship between globalisation and income equality since the former is known to be one of the causes of the latter. There have been so many debates as to which direction does globalisation affect income inequality. Mills (2009) opines that globalisation is related to inequality with contrary views. Some authors (Alderson \& Nielsen, 2002; Bergh \& Nilsson, 2010; Wade, 2004) argue that globalisation, especially through trade openness or foreign direct investment or financial liberalisation, contributes to unequal income distribution within and between countries, as mostly seen in the developed countries.

Contrarily, some authors argue that globalisation helps to reduce inequality across and within economies, especially in developing countries (Marjit, Beladi, \& Chakrabarti, 2004). This implies that there are conflicting arguments based on the globalisation-inequality nexus, hence, evidence that globalisation has many roles to play in influencing inequality in an economy. There are exhaustive studies on the relationship between globalisation and income inequality in the literature. Base on this, different measures of globalisation are used by these authors. Among the measures used are trade openness, foreign direct investment (FDI), financial liberalisation, and technological globalisation. Only a few studies (see Dreher and Gaston (2008)) employ all the three dimensions of globalisation-economic, social, and political globalisation. This review is coming from the three strands of findings in the literature since the nexus between globalisation and income inequality is contradictory.

The first strand of the literature comes from the argument that the more an economy is integrated with other countries, the lower the level of income inequality. In other words, the authors establish that there is a negative relationship between globalisation and income inequality. This argument is in line with the findings of Baiardi and Morana (2018) in the euro area; Baek and Shi (2016) using trade intensity in 52 developing countries and financial integration in 26 developed countries; Bukhari and Munir (2016) with trade and technological globalisation in some selected Asian countries; Kratou and Goaied (2016) in 66 developing countries; Lim and McNelis (2016) across 214 countries; Trinh (2016) across Vietnam's provinces; Mihaylova (2015) with FDI, level of education and economic growth, for 10 post-socialist countries from Central and Eastern Europe; Msweli (2015) in South Africa; Mugeni (2015) using a panel dataset of 153 developing and developed countries; Asteriou, Dimelis, and Moudatsou (2014) in EU-27 countries using financial globalisation; Farhan, Azman-Saini, and Law (2014) in ASEAN-5; Herzer, Hühne, and Nunnenkamp (2014) in Uruguay; Salimi, Akhoondzadeh, and Arsalanbod (2014) in 30 developed and developing countries; Deng and Lin (2013) among 102 countries with insufficient human capital; Jaumotte et al. (2013) with trade openness in 51 countries; Wu and Hsu (2012) in countries with improved absorptive capacity; David (2011) using trade openness for 27 Brazillian states; Faustino and Vali (2011) using trade openness in OECD countries; Figini and Gorg (2011) in developed countries; Herzer and Nunnenkamp (2011) in the European countries; Zhou, Biswas, Bowles, and Saunders (2011) in 60 developed, transitional and developing countries; Celik and Basdas (2010) for both developed and developing countries; Chintrakarn, Herzer, and Nunnenkamp (2010) in the United States; Mills (2009) in developing countries; Dreher and Gaston (2008) in 123 countries; Bhandari (2007) with wage income and capital income inequality in transitional countries in Eastern Europe and Central Asia; Blinder (2006) in the United States; Reuveny and Li (2003) in 69 countries; Beer and Boswell (2002) using a cross-sectional analysis; Alderson and Nielsen (1999) in 88 countries; and Spilimbergo, Londoño, and Székely (1999) in capital-rich countries.

Contrarily, the second strand of the literature shows that the process of globalisation causes income inequality to increase, thus, a positive association between the two variables. The following studies are in tandem with this submission, De Haan and Sturm (2017) for 121 countries; Dorn, Fuest, and Potrafke (2017) using KOF globalisation index across 140 developing and developed countries; Nguyen (2017) in the United States; Baek and Shi (2016) using trade intensity in 26 developed countries and financial integration in 52 developing countries; Bukhari and Munir (2016) with financial globalisation in some selected Asian countries; Cabral, García-Díaz, and Mollick (2016) for 15 economies (Mahesh, 2016) in Brazil, Russia, India, and China; Liu, Liu, and Zhang (2016) for a panel of 23 Chinese Provinces; Suanes (2016) in Latin America; Amjad (2015); Asteriou et al. (2014); Kutor (2014) in Ghana; Herzer et al. (2014) in Bolivia, Chile, and Columbia; Zulfiu-Alili (2014) in Macedonia; Deng and Lin (2013) among 102 countries with sufficient human capital; Herzer. and Nunnenkamp (2013); Jaumotte et al. (2013) with financial globalisation in 51 countries in EU-27 countries using trade opennes; Atif et al. (2012) in 68 developing countries; Herzer and Nunnenkamp (2012) for 21 countries; Wu and Hsu (2012) in countries with low absorptive capacity; David (2011) using FDI for 27 Brazillian states Figini and Gorg (2011) in developing countries; Halmos (2011) for Eastern European countries; Bergh and Nilsson (2010) for 80 countries; Celik and Basdas (2010) for East Asian countries; Basu and Guariglia (2007) on 119 developing countries; Nunnenkamp, Schweickert, and Wiebelt (2007) in Bolivia; Mills (2009) in developed countries; Kahai and Simmons (2005) in developing countries; Zhang and Zhang (2003) in China; Choi (2006) in Asia, Latin America and Caribbean countries; Mah (2002) in South Korea; and Spilimbergo et al. (1999) in labour-rich countries.

The last strand of the literature reveals that globalisation has no significant effect on income inequality as shown in the studies of Okatan (2011) among 92 selected developing countries; Kahai and Simmons (2005) in developed countries; Sylwester (2005) in 29 developing countries; Faustino and Vali (2011) using FDI in OECD countries; Bhandari (2007) in transitional countries in Eastern Europe and Central Asia; Mah (2003) with FDI, in South Korea; and Milanovic (2005) with FDI in 88 countries.

Additionally, there are few studies on each of the MINT countries. For instance, In Mexico, Herzer et al. (2014) show that globalisation (FDI) increases income inequality. The direct nexus supports the Feenstra and Hanson (1997) hypothesis which states that the process of globalisation worsens inequality. On the other hand, Harrison and Hanson (1999) using trade openness as a measure of globalisation show that states with a high level of globalisation experience a higher increase in incomes which translates to reduced inequality. Borraz and LopezCordova (2007) find the same result that states that are closely related to other countries would experience more 
equal distribution of incomes and lower inequality due to increasing wages for women compared to those that are not integrated with other countries. To corroborate this finding, Jensen and Rosas (2007) affirm that FDI reduces income inequality. In Indonesia, Agusalim and Pohan (2018) confirm that globalisation (trade openness) helps in reducing inequality in the short run but otherwise in the long run, while Lipsey and Sjoholm (2001) argue that globalisation (FDI inflows) causes income inequality to rise.

In Nigeria, Babatunde (2018) studies the effect of inward FDI on income inequality the short- and long-run symmetric results reveal that the lagged values of FDI tend to reduce the unequal distribution of income. Looking at the short-run asymmetric result, the positive and negative FDI shocks reduce and increase income inequality, respectively. The long-run asymmetric results are found to be inconclusive. While, Ogunyomi, Daisi, and Oluwashikemi (2013) study the effect of economic globalisation on income inequality and economic growth and the results show that economic globalisation increased inequality and reduces economic growth. the three tiers of government, provision of infrastructural facilities, and promotion of entrepreneurial capabilities in the non-oil sector to reduce inequality between the skilled and unskilled workers. Lastly, In Turkey, Ucal, Haug, and Bilgin (2015) argue that globalisation (FDI) significantly reduces income inequality in both the short-and long-run. This is against the study of Ucal, Bilgin, and Haug (2014) in Turkey where FDI adds to income inequality.

Meanwhile, few of these studies test for the validity of Kuznets' hypothesis. Among the studies that support this hypothesis are Lee (2014) and Bukhari and Munir (2016) while Mah (2003) and Dreher and Gaston (2008) reject the hypothesis. Conclusively, evidence from the previous studies reveals than globalisation could either reduce or increase income inequality. Also, the effect of globalisation on income inequality could be insignificant. However, none of the studies tests for the validity of Kuznets' hypothesis and examines the effect of overall globalisation and its dimensions on income inequality by studying the MINT countries together. This current study intends to fill the gaps.

\section{Data Description and Methodology \\ 3.1. Data Description}

Data on economic growth, as measured by GDP per capita in constant US\$ (GDPPC), human capital, as proxied by secondary school enrolment rate (HUMC), population growth (POP), and inflation rate (INF) are gotten from WDI (2018) data on corruption, as captured by control of corruption, is sourced from International Country Risk Guide (ICRG, 2018); GINI coefficient, as a measure of income inequality (YINQ), is obtained from SWIID (2018) and data on economic (EGB), social (SGB), political (PGB) and overall globalisation (GBI) are gathered from Konjunkturforschungsstelle globalisation index (KOF, 2018). All the variables under consideration are time series which range between 1980 and 2018. Notably, the study interpolates missing data points using a 4year moving average and the variables are in their natural logarithmic form to reduce non-normality.

\subsection{Methodology}

\subsubsection{Theoretical framework}

The theoretical framework for this study stems from the traditional neoclassical trade theory. The simplest form of the neoclassical trade theory is the Ricardo (1817) theory of comparative advantage. And, as time went by, the Heckscher (1919); Ohlin (1933) theory of comparative advantage was produced as an alternative to the Ricardian model. According to the theory, reductions in trade barriers and trade costs would encourage convergence of factor prices and income levels. This is because the removal or reductions in trade restrictions would bring about specialization and factor accumulation that would be beneficial to all, irrespective of the initial economic condition of the country involved. Another point of argument of the neoclassical theory is the claim that globalisation attracts domestic and foreign investment that increases the rate of capital accumulation and employment opportunities, thus reduces the level of income inequality. Also, Todaro and Smith (2015) established that the process of globalisation improves greater access to foreign production ideas that will lead to technological progress. Interestingly, even the modern trade theory, that is, Hecksher-Ohlin trade theory, is based on the neoclassical trade theory. The Hecksher-Ohlin trade theory assumes perfect competition and asserts that trade enhances people's well-being as a result of distributing factors of production across all sectors of the economy.

\subsubsection{Model Specification}

Following the theoretical framework, the following model by Jaumotte et al. (2013); Lee (2014); Mihaylova (2015) and Baek and Shi (2016) is adapted. The model states that income inequality is a function of globalisation and the model is shown in Equation 1.

$$
Y I N Q_{t}=f\left(G B_{t}, X_{t}\right)
$$

where $Y I N Q_{t}$ : Income Inequality measure, that is, GINI index.

$G B_{t}$ : measure of globalization.

$X_{t}$ : control variables

However, to account for the various dimensions of globalisation, that is, economic, social and political globalisation, Equation 1 is modified to include the various dimensions. This is because the process of globalisation is more than economic phenomena as captured in some studies but it includes the intensification of economic, political and social relations across international boundaries (Fafowora, 1998).

Therefore, Equation 1 can be re-written as:

$$
Y I N Q_{t}=f\left(E G B_{t}, S G B_{t}, P G B_{t}, X_{t}\right)
$$

Where $E G B_{t}$ : Economic globalisation at time $t$.

$S G B_{t}$ : Social globalisation at time $t$.

$P G B_{t}$ : Political globalisation at time $t$. 
From Equation 2, income inequality is the endogenous variable, while globalisation and other control variables are the exogenous variables. The control variables used in this study include economic growth, human capital, population growth, inflation, and control of corruption. The choice of these variables is based on their significance in affecting the level of income inequality in each of the MINT economies and also, on the fact that they have been found useful by other studies as discussed below.

For economic growth, it is expected that improved economic growth should help in reducing income inequality. This calls for the inclusion of economic growth (that is, GDP per capita) into the model (Baek \& Shi, 2016; Im \& McLaren, 2015; Jaumotte et al., 2013; Lee, 2014; Mihaylova, 2015; Rye, 2016). Human capital is added because education is a key factor in human development as it provides widespread employment and income-earning opportunities for all (Baek \& Shi, 2016; Bukhari \& Munir, 2016; Lee, 2014; Mihaylova, 2015).

Also, population growth is included in the model following some studies like Im and McLaren (2015); Bukhari and Munir (2016) and Rye (2016) because a high population is detrimental to share of national resources and all the MINT countries have a large population. The idea is that population growth adds to income inequality and slows down the prospects for a better life for those already born.

To capture the macroeconomic stability of the economy, inflation is added to the model. Inflation is therefore important in determining the relationship between globalisation and income inequality because a high inflation rate can reduce the purchasing power of the country's currency leading to high level of income inequality (see Mihaylova (2015)). Lastly, in examining the institutional impact on globalisation-inequality nexus, control of corruption is added to the model. Also, corruption is included because all the MINT countries scored badly in Transparency International's Corruption Perception Index (2014) Turkey ranked 64 out of 175, while the rest were closer to the other end of the scale (Matsangou, 2015). Corruption will eventually lead to an increase in the rate of unemployment and income inequality (see Kahai and Simmons (2005)).

Hence, to include all the control variables and to take care of the country-specific analysis, Equation 2 is respecified as follows:

$$
\begin{aligned}
& Y I N Q_{i t}=f\left(E G B_{i t}, S G B_{i t}, P G B_{i t}, G D P P C_{i t}, H U M C_{i t}, P O P_{i t}, I N F_{i t}, C O R_{i t}\right) \\
& Y I N Q_{i t}=f\left(G B I_{i t}, G D P P C_{i t}, H U M C_{i t}, P O P_{i t}, I N F_{i t}, C O R_{i t}\right)
\end{aligned}
$$

Explicitly, Equations 3 and 4 are stated below to include the stochastic form:

$$
\begin{gathered}
Y I N Q_{i t}=\alpha_{i}+\beta_{i} E G B_{i t}+\chi_{i} S G B_{i t}+\delta_{i} P G B_{i t}+\phi_{i} G D P P C_{i t}+\varphi_{i} H U M C_{i t}+\gamma_{i} P O P_{i t}+\kappa_{i} I N F_{i t}+\lambda_{i} C O R_{i t}+\varepsilon_{i t} \\
Y I N Q_{i t}=\alpha_{i}+\varpi_{i} G B I_{t}+\phi_{i} G D P P C_{t}+\varphi_{i} H U M C_{t}+\gamma_{i} P O P_{t}+\kappa_{i} I N F_{t}+\lambda_{i} C O R_{t}+\varepsilon_{t}
\end{gathered}
$$

Note that, subscripts $i$ and $t$ capture the countries involved in this study (i.e. Mexico, Indonesia, Nigeria, and Turkey) and the period for the study (i.e.1980-2018), respectively. Also, Equation 5 is used to examine the relative effects of the dimensions of globalisation on income equality, while Equation 6 determines the effect of overall globalisation on income inequality.

Where $G B I_{i t}$ : Overall Globalisation Index in each of the MINT countries at time $t$.

$Y I N Q_{i t}$ : Gini coefficient in each of the MINT countries at time $t$.

$G D P P C_{i t}$ : GDP per capita in each of the MINT countries at time $t$.

$H U M C_{i t}$ : Human capital in each of the MINT countries at time $t$.

$P O P_{i t}$ : Population growth in each of the MINT countries at time $t$.

$I N F_{i t}$ : Inflation rate in each of the MINT countries at time $t$.

$C O R_{i t}$ : Control of Corruption in each of the MINT countries at time $t$.

$\varepsilon_{i t}$ : Error term in each of the MINT countries at time $t$.

\subsubsection{Estimation Technique}

A dynamic Generalised Method of Moments is employed to achieve the study objectives. This technique of estimation is preferred because of its strengths over other methods like descriptive statistics and OLS. The GMM technique possesses four major strengths according to Bond, Hoeffler, and Temple (2001) and Wooldridge (2001) which are; it gives unbiased estimates when some variables are omitted, it generates consistent estimates with measurement error, it helps in solving the problem of endogeneity and non-normality in the data.

A key econometric issue to be addressed is the potential issue of endogeneity that might arise among the variables of interest. The idea is that the exogenous variables can be endogenously determined, meaning that income inequality can influence globalisation. For instance, income inequality affects globalisation through credit market imperfections, indivisibilities in investment and lower GDP per capita that brings about political and social instability, lower investment, unproductive rent-seeking activities which will all affect the integration of an economy with others. This shows that globalisation cannot be strictly treated as an explanatory variable.

To determine how income inequality responds to globalisation, Equations 5 and 6 are modified using a dynamic GMM approach. The models are also used to test for the validity or otherwise of the Kuznets' inverted-U hypothesis in all the MINT countries. To achieve this, the square of the level of growth (GDP per capita) is added to the models. According to Lee (2014) and Mihaylova (2015), globalisation is said to exert both direct and conditional effects on inequality and the conditional variables used following Lee (2014) and Mihaylova (2015) are levels of education and growth. To test for the conditional effect of globalisation, the interactive terms of overall globalisation index and level of education (HUMC) and level of growth (GDP) are used in the regression models. Therefore, these are used to capture the interactive (joint or conditional) effects of globalisation and each of economic growth and education on income inequality as shown in Equations 7 and 8. 
$Y I N Q_{i t}=\alpha_{i}+\psi_{i} Y I N Q_{i t-1}+\beta_{i} E G B_{i t}+\chi_{i} S G B_{i t}+\delta_{i} P G B_{i t}+\phi_{1 i} G D P P C_{i t}+\phi_{2 i} G D P P C^{2}{ }_{i t}+\varphi_{i} H U M C_{i t}+\gamma_{i} P O P_{i t}+$

$\kappa_{i} I N F_{i t}+\lambda_{i} C O R_{i t}+\varepsilon_{i t}$

$Y I N Q_{i t}=\alpha_{i}+\psi_{i} Y I N Q_{i t-1}+\varpi_{i} G B I_{i t}+\phi_{1 i} G D P P C_{i t}+\phi_{2 i} G D P P C_{i t}^{2}+\varphi_{i} H U M C_{i t}+\gamma_{i} P O P_{i t}+\kappa_{i} I N F_{i t}+\lambda_{i} C O R_{i t}+$

$v_{i}(G B I * G D P P C)_{i t}+\zeta_{i}(G B I * H U M C)_{i t}+\varepsilon_{i t}$

$Y I N Q_{i t-1}=$ Previous value of income inequality in each of the MINT countries at time $t$.

For strong evidence of Kuznets' inverted-U hypothesis, $\phi_{1 i}$ and $\phi_{2 i}$ must be significantly positive and negative, respectively, which implies that income inequality rises as an economy develops to some threshold level and thereafter, inequality starts to fall.

\section{Results and Discussion of Findings}

4.1. Descriptive Statistics

Tables 1a-b display the descriptive statistics of the variables involved. The results show that all the variables in each of the MINT countries are consistent because their mean values fall between the minimum and maximum values. Specifically, the average values of YINQ are 0.46, 0.38, 0.39, and 0.43 in Mexico, Indonesia, Nigeria, and Turkey, respectively, while the average values of GBI are 58.09, 53.92, 49.10, and 60.59, respectively. Other values are reported in Tables 1a-b. Also, the standard deviation values reveal that the variables do not deviate from their mean values.

Table-1a. Descriptive statistics of the variables for Mexico and Indonesia.

\begin{tabular}{|c|c|c|c|c|c|c|c|}
\hline Country & Variable & Mean & Median & Max. Value & Min. Value & Std. Dev. & Obs. \\
\hline \multirow{10}{*}{ Mexico } & YINQ & 0.46 & 0.46 & 0.48 & 0.45 & 0.01 & 39 \\
\hline & EGB & 47.15 & 48.34 & 60.86 & 31.89 & 9.17 & 39 \\
\hline & SGB & 54.72 & 53.83 & 67.75 & 40.38 & 10.18 & 39 \\
\hline & PGB & 72.41 & 73.25 & 94.81 & 58.09 & 9.10 & 39 \\
\hline & GBI & 58.09 & 58.08 & 74.33 & 44.79 & 9.16 & 39 \\
\hline & GDPPC & 0.91 & 1.58 & 6.63 & -7.98 & 3.28 & 39 \\
\hline & HUMC & 69.78 & 67.84 & 103.34 & 44.87 & 16.86 & 39 \\
\hline & POP & 1.69 & 1.61 & 2.41 & 1.22 & 0.34 & 39 \\
\hline & INF & 25.20 & 9.49 & 131.82 & 2.72 & 33.19 & 39 \\
\hline & $\mathrm{COR}$ & 2.54 & 2.50 & 3.42 & 1.81 & 0.50 & 39 \\
\hline \multirow{10}{*}{ Indonesia } & YINQ & 0.38 & 0.37 & 0.43 & 0.36 & 0.03 & 39 \\
\hline & EGB & 50.58 & 50.68 & 69.69 & 37.30 & 8.61 & 39 \\
\hline & SGB & 36.05 & 37.52 & 54.36 & 17.14 & 12.92 & 39 \\
\hline & PGB & 75.14 & 77.32 & 87.56 & 59.40 & 9.98 & 39 \\
\hline & GBI & 53.92 & 58.14 & 64.23 & 38.11 & 9.56 & 39 \\
\hline & GDPPC & 3.50 & 3.92 & 7.32 & -14.35 & 3.36 & 39 \\
\hline & HUMC & 57.39 & 54.43 & 90.60 & 26.45 & 18.06 & 39 \\
\hline & POP & 1.58 & 1.40 & 2.36 & 1.06 & 0.37 & 39 \\
\hline & INF & 9.50 & 7.82 & 58.45 & 2.88 & 8.87 & 39 \\
\hline & COR & 1.88 & 2.00 & 3.58 & 0.00 & 1.13 & 39 \\
\hline
\end{tabular}

Table-1b. Descriptive statistics of variables for Nigeria and Turkey.

\begin{tabular}{|c|c|c|c|c|c|c|c|}
\hline Country & Variable & Mean & Median & Max. Value & Min. Value & Std. Dev. & Obs. \\
\hline \multirow{10}{*}{ Nigeria } & YINQ & 0.39 & 0.39 & 0.41 & 0.36 & 0.01 & 39 \\
\hline & EGB & 46.55 & 46.52 & 60.12 & 35.45 & 6.19 & 39 \\
\hline & SGB & 24.04 & 19.30 & 39.85 & 12.45 & 9.97 & 39 \\
\hline & PGB & 76.71 & 78.59 & 86.98 & 60.34 & 8.93 & 39 \\
\hline & GBI & 49.10 & 50.87 & 57.55 & 40.00 & 5.94 & 39 \\
\hline & GDPPC & 0.68 & 1.20 & 30.36 & -15.45 & 7.19 & 39 \\
\hline & HUMC & 33.37 & 28.28 & 72.28 & 13.67 & 15.17 & 39 \\
\hline & POP & 2.59 & 2.59 & 2.86 & 2.49 & 0.08 & 39 \\
\hline & INF & 19.25 & 12.88 & 72.84 & 5.38 & 17.05 & 39 \\
\hline & COR & 1.62 & 1.50 & 2.00 & 1.00 & 0.35 & 39 \\
\hline \multirow{10}{*}{ Turkey } & YINQ & 0.43 & 0.43 & 0.46 & 0.39 & 0.02 & 39 \\
\hline & EGB & 48.48 & 50.72 & 56.47 & 32.79 & 6.73 & 39 \\
\hline & SGB & 50.67 & 51.35 & 66.79 & 34.51 & 11.32 & 39 \\
\hline & PGB & 82.63 & 86.79 & 92.82 & 63.54 & 10.34 & 39 \\
\hline & GBI & 60.59 & 63.13 & 71.67 & 44.41 & 9.13 & 39 \\
\hline & GDPPC & 2.90 & 3.77 & 9.47 & -7.36 & 4.23 & 39 \\
\hline & HUMC & 71.40 & 71.69 & 119.65 & 37.56 & 23.89 & 39 \\
\hline & POP & 1.66 & 1.59 & 2.28 & 1.20 & 0.30 & 39 \\
\hline & INF & 40.22 & 37.61 & 105.22 & 6.25 & 30.74 & 39 \\
\hline & $\mathrm{COR}$ & 2.68 & 2.50 & 4.00 & 2.00 & 0.54 & 39 \\
\hline
\end{tabular}


Table-2a. Unit root tests (with intercept and trend) for Mexico, Indonesia, Nigeria, and Turkey.

\begin{tabular}{|c|c|c|c|c|c|c|c|c|c|c|}
\hline \multirow[t]{2}{*}{ Country } & \multirow[t]{2}{*}{ Variable } & \multicolumn{3}{|c|}{ ADF Test (with intercept and Trend) } & \multicolumn{3}{|c|}{ PP Test (with intercept and Trend) } & \multicolumn{3}{|c|}{ KPSS (with intercept and Trend) } \\
\hline & & Level & First Difference & Order & Level & First Difference & Order & Level & First Difference & Order \\
\hline \multirow{4}{*}{ Mexico } & EGB & $-4.25 * *$ & - & $\mathrm{I}(0)$ & -2.59 & $-7.53 * *$ & $\mathrm{I}(1)$ & $0.08 * *$ & - & $\mathrm{I}(\mathrm{o})$ \\
\hline & HUMC & $-5.24 * *$ & - & $\mathrm{I}(0)$ & -1.96 & $-3.22 *$ & $\mathrm{I}(1)$ & $0.10^{* * *}$ & - & $\mathrm{I}(\mathrm{O})$ \\
\hline & COR & $-4.98 * *$ & - & $\mathrm{I}(0)$ & $-4.95 * *$ & - & $\mathrm{I}(0)$ & - & - & - \\
\hline & GBI*HUMC & $-3.62 * *$ & - & $\mathrm{I}(\mathrm{O})$ & -1.71 & $-4.12^{* *}$ & $\mathrm{I}(1)$ & $0.09 * *$ & - & $\mathrm{I}(\mathrm{O})$ \\
\hline Nigeria & GBI & -1.94 & -4.80 *** & $\mathrm{I}(1)$ & -2.13 & $-6.03 * *$ & $\mathrm{I}(1)$ & - & - & - \\
\hline \multirow{3}{*}{ Indonesia } & SGB & 0.51 & -3.56 *** & $\mathrm{I}(1)$ & -0.43 & $-6.87 * *$ & $\mathrm{I}(1)$ & - & - & - \\
\hline & POP & $-4.21 * *$ & - & $\mathrm{I}(0)$ & -1.52 & $-3.56^{* *}$ & $\mathrm{I}(1)$ & 0.16 & $0.14^{* * *}$ & $\mathrm{I}(1)$ \\
\hline & INF & $-4.84 * *$ & - & $\mathrm{I}(0)$ & $-4.77 * *$ & - & $\mathrm{I}(0)$ & - & - & - \\
\hline \multirow{6}{*}{ Turkey } & EGB & -2.37 & $-7.48 * *$ & $\mathrm{I}(1)$ & -2.26 & $-8.81 * *$ & $\mathrm{I}(1)$ & - & - & - \\
\hline & GBI & -0.78 & $-6.58^{* * *}$ & $\mathrm{I}(1)$ & -0.69 & $-6.91 * *$ & $\mathrm{I}(1)$ & - & - & - \\
\hline & POP & -0.08 & $-6.03 * *$ & $\mathrm{I}(1)$ & -1.10 & $-6.03 * *$ & $\mathrm{I}(1)$ & - & - & - \\
\hline & Critical Values & Level & First Difference & Critical Values & Level & First Difference & Critical Values & Level & First Difference & \\
\hline & $5 \%$ & -3.54 & -3.56 & $5 \%$ & -3.53 & -3.54 & $5 \%$ & 0.15 & 0.15 & \\
\hline & $10 \%$ & -3.20 & -3.22 & $10 \%$ & -3.20 & --3.20 & $10 \%$ & 0.12 & 0.12 & \\
\hline
\end{tabular}


Table-2b. Unit root tests (with intercept only) for Mexico, Indonesia, Nigeria, and Turkey.

\begin{tabular}{|c|c|c|c|c|c|c|c|}
\hline \multirow[b]{2}{*}{ Country } & \multirow[b]{2}{*}{ Variable } & \multicolumn{3}{|c|}{ ADF Test (with intercept only) } & \multicolumn{3}{|c|}{ PP Test (with intercept only) } \\
\hline & & Level & $\begin{array}{c}\text { First } \\
\text { Difference }\end{array}$ & Order & Level & $\begin{array}{c}\text { First } \\
\text { Difference }\end{array}$ & Order \\
\hline \multirow[b]{2}{*}{ Mexico } & SGB & -0.31 & $-5.59^{* *}$ & $\mathrm{I}(1)$ & -0.38 & $-5.59^{* * *}$ & $\mathrm{I}(1)$ \\
\hline & INF & -1.26 & $-5.86^{*} *$ & $\mathrm{I}(1)$ & -1.16 & $-6.60^{* * *}$ & $\mathrm{I}(1)$ \\
\hline \multirow{5}{*}{ Indonesia } & PGB & -1.10 & $-2.95 * *$ & $\mathrm{I}(1)$ & -1.10 & $-7.36^{* * *}$ & $\mathrm{I}(1)$ \\
\hline & GBI & -1.85 & $-4.92 * *$ & $\mathrm{I}(1)$ & -1.85 & $-4.92 * *$ & $\mathrm{I}(1)$ \\
\hline & HUMC & -2.12 & $-4.09 * *$ & $\mathrm{I}(1)$ & -1.88 & -4.06 ** & $\mathrm{I}(1)$ \\
\hline & GBI*GDPPC & -1.37 & $-4.41 * *$ & $\mathrm{I}(1)$ & -1.27 & -4.43 & $\mathrm{I}(1)$ \\
\hline & GBI*HUMC & -2.51 & $-4.52 * *$ & $\mathrm{I}(1)$ & -2.51 & $-4.52^{* * *}$ & $\mathrm{I}(1)$ \\
\hline \multirow{3}{*}{ Nigeria } & POP & $-5.34^{* * *}$ & - & $\mathrm{I}(\mathrm{O})$ & $-3.58 * *$ & - & $\mathrm{I}(\mathrm{O})$ \\
\hline & INF & $-3.44^{* *}$ & - & $\mathrm{I}(\mathrm{O})$ & $-3.32 * *$ & - & $\mathrm{I}(\mathrm{O})$ \\
\hline & GBI*GDPPC & -0.42 & $-5.18 * *$ & $\mathrm{I}(1)$ & -0.33 & $-6.30^{* *}$ & $\mathrm{I}(1)$ \\
\hline \multirow{9}{*}{ Turkey } & SGB & -0.87 & $-4.90 * *$ & $\mathrm{I}(1)$ & -0.86 & $-4.85^{*} *$ & $\mathrm{I}(1)$ \\
\hline & PGB & -0.87 & $-4.65 * *$ & $\mathrm{I}(1)$ & -0.86 & -4.85 ** & $\mathrm{I}(1)$ \\
\hline & HUMC & -0.36 & $-6.21 * *$ & $\mathrm{I}(1)$ & -0.35 & $-6.21 * *$ & $\mathrm{I}(1)$ \\
\hline & COR & $-3.75^{* *}$ & - & $\mathrm{I}(\mathrm{O})$ & $-2.96^{* *}$ & - & $\mathrm{I}(\mathrm{O})$ \\
\hline & GBI*GDPPC & -1.04 & $-5.94 * *$ & $\mathrm{I}(1)$ & -1.07 & $-5.94 * *$ & $\mathrm{I}(1)$ \\
\hline & GBI*HUMC & -0.71 & $-6.30 * *$ & $\mathrm{I}(1)$ & -0.72 & $-6.30^{* * *}$ & $\mathrm{I}(1)$ \\
\hline & Critical Values & Level & $\begin{array}{c}\text { First } \\
\text { Difference }\end{array}$ & $\begin{array}{l}\text { Critical } \\
\text { Values }\end{array}$ & Level & $\begin{array}{c}\text { First } \\
\text { Difference }\end{array}$ & $\begin{array}{l}\text { Critical } \\
\text { Values }\end{array}$ \\
\hline & $5 \%$ & -2.94 & -2.94 & $5 \%$ & -2.94 & -2.94 & $5 \%$ \\
\hline & $10 \%$ & -2.61 & -2.61 & $10 \%$ & -2.61 & -2.61 & $10 \%$ \\
\hline
\end{tabular}

Note: ** and * represent 5 per cent and 10 per cent levels of significance, respectively

Table-2c. Unit root tests (without intercept and trend) for Mexico, Indonesia, Nigeria, and Turkey

\begin{tabular}{|c|c|c|c|c|c|c|c|}
\hline \multirow[t]{2}{*}{ Country } & \multirow[t]{2}{*}{ Variable } & \multicolumn{3}{|c|}{$\begin{array}{c}\text { ADF Test (without intercept and } \\
\text { Trend) }\end{array}$} & \multicolumn{3}{|c|}{$\begin{array}{c}\text { PP Test (without intercept and } \\
\text { Trend) }\end{array}$} \\
\hline & & Level & $\begin{array}{c}\text { First } \\
\text { Difference }\end{array}$ & Order & Level & $\begin{array}{c}\text { First } \\
\text { Difference }\end{array}$ & Order \\
\hline & YINQ & 0.23 & $-1.97 * *$ & $\mathrm{I}(1)$ & 0.68 & $-2.83 * *$ & $\mathrm{I}(1)$ \\
\hline & PGB & 1.70 & $-5.00 * *$ & $\mathrm{I}(1)$ & 2.24 & $-4.97 * *$ & $\mathrm{I}(1)$ \\
\hline \multirow[t]{5}{*}{ Mexico } & GBI & 3.32 & $-5.06 * *$ & $\mathrm{I}(1)$ & -5.66 & $-5.06 * *$ & $\mathrm{I}(1)$ \\
\hline & GDPPC & 1.36 & $-6.24 * *$ & $\mathrm{I}(1)$ & 1.70 & $-6.25^{* *}$ & $\mathrm{I}(1)$ \\
\hline & POP & $-3.03 * *$ & - & $\mathrm{I}(\mathrm{O})$ & $-2.15^{* *}$ & - & $\mathrm{I}(\mathrm{O})$ \\
\hline & GBI*GDPPC & -3.95 & $-2.48 * *$ & $\mathrm{I}(1)$ & 4.04 & $-4.55^{* *}$ & $\mathrm{I}(1)$ \\
\hline & YINQ & -1.14 & $-6.73 * *$ & $\mathrm{I}(1)$ & -1.46 & $-1.62 * *$ & $\mathrm{I}(1)$ \\
\hline \multirow[t]{6}{*}{ Indonesia } & EGB & 0.52 & $-4.97 * *$ & $\mathrm{I}(1)$ & -1.79 & $-4.95 * *$ & $\mathrm{I}(1)$ \\
\hline & GDPPC & 5.80 & $-3.11 * *$ & $\mathrm{I}(1)$ & -5.80 & $-3.01 * *$ & $\mathrm{I}(1)$ \\
\hline & COR & -1.31 & $-6.32 * *$ & $\mathrm{I}(1)$ & -1.52 & $-6.37 * *$ & $\mathrm{I}(1)$ \\
\hline & YINQ & -0.92 & $-1.83^{*}$ & $\mathrm{I}(1)$ & -0.92 & $-2.07 * *$ & $\mathrm{I}(1)$ \\
\hline & EGB & -0.32 & $-6.22 * *$ & $\mathrm{I}(1)$ & -0.38 & $-6.45 * *$ & $\mathrm{I}(1)$ \\
\hline & SGB & 0.86 & $-3.61 * *$ & $\mathrm{I}(1)$ & 1.11 & $-3.58 * *$ & $\mathrm{I}(1)$ \\
\hline \multirow[t]{6}{*}{ Nigeria } & PGB & 1.23 & $-7.25 * *$ & $\mathrm{I}(1)$ & 1.29 & $-7.14 * *$ & $\mathrm{I}(1)$ \\
\hline & GDPPC & 4.49 & $-4.47 * *$ & $\mathrm{I}(1)$ & 5.70 & $-4.65 * *$ & $\mathrm{I}(1)$ \\
\hline & HUMC & 2.93 & $-3.85 * *$ & $\mathrm{I}(1)$ & 2.07 & $-3.77 * *$ & $\mathrm{I}(1)$ \\
\hline & COR & -1.08 & $-3.98 * *$ & $\mathrm{I}(1)$ & -1.04 & $-3.91 * *$ & $\mathrm{I}(1)$ \\
\hline & GBI*HUMC & 3.16 & $-4.35^{* *}$ & $\mathrm{I}(1)$ & 2.50 & $-4.33^{* * *}$ & $\mathrm{I}(1)$ \\
\hline & YINQ & 0.66 & $-1.83 *$ & $\mathrm{I}(1)$ & 0.31 & $-1.69 *$ & $\mathrm{I}(1)$ \\
\hline \multirow[t]{5}{*}{ Turkey } & GDPPC & 4.49 & $-4.47 * *$ & $\mathrm{I}(1)$ & 5.70 & $-4.65 * *$ & $\mathrm{I}(1)$ \\
\hline & INF & -1.39 & $-6.04 * *$ & $\mathrm{I}(1)$ & -1.34 & $-6.05 * *$ & $\mathrm{I}(1)$ \\
\hline & $\begin{array}{l}\text { Critical } \\
\text { Values }\end{array}$ & Level & $\begin{array}{c}\text { First } \\
\text { Difference }\end{array}$ & Critical Values & Level & $\begin{array}{c}\text { First } \\
\text { Difference }\end{array}$ & Critical Values \\
\hline & $5 \%$ & -1.95 & -1.95 & $5 \%$ & -1.95 & -1.95 & $5 \%$ \\
\hline & $10 \%$ & -1.61 & -1.61 & $10 \%$ & -1.61 & -1.61 & $10 \%$ \\
\hline
\end{tabular}

Note: ** and * represent 5 per cent and 10 per cent levels of significance, respectively.

\subsection{Unit Root Test}

We next determine the stationarity of the variables of interest. Time series are assumed not to be stationary and to avoid wrong conclusions, it is important to carry out a unit root test. To do this, the study uses Augmented Dickey-Fuller (ADF), Phillips-Perron (PP) and Kwiatkowski-Phillips-Schmidt-Shin (KPSS) tests. The null hypothesis of non-stationary will be rejected if the test statistic from the ADF and PP tests is greater than the critical value (in absolute term) at either 5 per cent or 10 per cent level of significance, while the null hypothesis of stationarity will be accepted if the test statistic from the KPSS test is less than the critical value.

The KPSS test is involved to confirm the results of the ADF and PP tests. Importantly, the KPSS test is only used for those variables, specifically for Mexico's EGB, HUMC, and GBI*HUMC, and Indonesia's POP, where both ADF and PP tests showed different orders of stationarity. Therefore, the order of stationarity for such variables is based on the KPSS test. However, the included variables use different equations for them to be stationary in all the MINT countries. Consequently, both ADF and PP tests are carried out with intercept and trend, with intercept only and without intercept and trend while the KPSS test is carried out with only intercept and trend as shown in Tables $2 \mathrm{a}-\mathrm{C}$. As observed in Tables $2 \mathrm{a}-\mathrm{C}$, all the variables are stationary at the first difference, that is, they are I(1) in all the MINT countries, except Mexico's EGB, HUMC, and GBI*HUMC; Nigeria's POP and INF; and Turkey's COR. 


\subsection{Kuznets' Hypothesis and the Relative Effects of the Components of Globalisation on Income Inequality}

To start with, the results of the GMM estimates in Tables 3 and 4 show that the estimated parameters are reliable and robust based on the diagnostic statistics. The probability values ( $\mathrm{p}$-value) of J-statistic being insignificant, in both tables, indicate the validity of the instrumental variables used. Also, the instrumental ranks are higher than the number of the estimated parameters and the insignificant p-values of $\operatorname{AR}(2)$ show that there is no serial correlation in the differentiated residuals. Table 3 shows that the previous value of income inequality increases its current value in each of the MINT countries. This reflects the consequence of the past level of income inequality by increasing the present status of inequality in each of the MINT countries. It also shows that the Gini coefficient is a stable index for computing inequality over time. When examining the relative effects of the components of globalisation on income inequality, there is strong evidence of Kuznets' hypothesis of an inverted Ushaped association between economic growth and inequality in each of the MINT countries as observed in Table 3. The findings support the empirical evidence from the works of Lee (2014); Mihaylova (2015) and Bukhari and Munir (2016). The implication is that income inequality in Mexico, Indonesia, Nigeria, and Turkey will first increase as their economies reach a certain level, and thereafter inequality will start to decline as they become more economically developed and richer. Economic globalisation affects income inequality positively and significantly in Mexico and Turkey at 5 per cent and 10 per cent level of significance, respectively, and this may be as a result of relative factor endowments and the levels of protection that emerged before the process of globalisation. This is in line with the earlier works of Mahesh (2016); Amjad (2015); Lee (2014); Ogunyomi et al. (2013); Atif et al. (2012); Bergh and Nilsson (2010) and Dreher and Gaston (2008). In Indonesia and Nigeria, its effect is insignificant and this is consistent with the studies of Dorn et al. (2017); Faustino and Vali (2011); Sylwester (2005); Dollar and Kraay (2002) and Mihaylova (2015). The positive impact in Mexico confirms the evidence that the process of income convergence ended in 1985 as a result of trade liberalisation. Thus, globalisation caused people living in Northern Mexico to become wealthier than those in Southern Mexico. While in Turkey, it could be as a result of an increase in unemployment from the abandonment of economic development and industrialization with public investments. On the other hand, social globalisation has a significant and positive impact on income inequality in all the MINT countries, except in Turkey where the effect is negative and significant at 5 per cent significant level. The negative effect follows the findings of Dreher and Gaston (2008). The reason for the positive relationship could be credited to the fact that there are some weak policies, in terms of social reforms, threatening the rise of social globalisation in Mexico, Indonesia, and Nigeria. But, the negative impact of social globalisation in Turkey may be because Turkey as one of the MINT countries has the most strategic locations given its transcontinental status between Asia and Europe. The negative impact of political globalisation on income inequality in Nigeria and Turkey at 5 per cent level of significance is in line with the theoretical proposition, but inequality increases at 10 per cent significant level in Mexico as a result of rising political globalisation (Dreher \& Gaston, 2008). Therefore, Nigeria and Turkey might be able to benefit from other countries in terms of international treaties and number of embassies in their economies which help to increase investment and job opportunities and thus, reduce income inequality, while Mexico was unable to benefit from political globalisation in terms of rising inequality because Mexico's government is seen to be institutionally inclined towards dishonesty and failure or unwillingness to seriously deal with drug dealers.

Furthermore, level of education as captured by human capital, using secondary school enrolment rate, significantly affects inequality in all the MINT countries at 5 per cent significance level, except in Indonesia where its impact is positive and insignificant and this confirms the findings of Asteriou et al. (2014). In Mexico, the effect is inverse (Bukhari \& Munir, 2016; MacDonald \& Majeed, 2010; Salimi et al., 2014; Trinh, 2016; Ucal et al., 2015) and this implies that as more people get educated, the level of income inequality will reduce because education will afford them good job opportunities. In other words, a higher level of education results in an increase in the supply of skilled labour force, which in turn, leads to a decrease in skilled wage premium, hence, lowering overall inequality (Mihaylova, 2015). Contrarily, the impact is direct in Nigeria and Turkey as against extant studies and this shows that the level of income inequality will continue to rise as people get higher education. For instance, in Nigeria, employers now attach importance to the level of education in getting well-paid jobs rather than the minimum educational qualification required for the job. This is because the country has a situation of many people seeking for jobs. Interestingly, population growth in all the MINT countries is statistically significant at 5 per cent level and support the theoretical position that income inequality should increase as population increases, except Nigeria that shows otherwise. In Mexico, Indonesia and Turkey, an increase in population will reduce the prospects for a better life for those already born and also, reduces limited government revenues to provide basic amenities. This supports the empirical evidence from the works of Trinh (2016) and MacDonald and Majeed (2010). In Nigeria, the result shows that population growth is desirable and should help in reducing income inequality (Amjad, 2015; David, 2011; Ucal et al., 2015). This infers that population growth in a country like Nigeria should not constitute a problem because it might cause consumer demand to increase leading to an increase in production and hence, might increase investment and employment opportunities that will help in reducing inequality. Another interesting result is found for inflation rate and control of corruption as they affect income inequality significantly at a 5 per cent level. The inflation rate has a positive effect on income inequality in all the MINT countries apart from Indonesia where the impact is negative. The positive impact confirms the a priori expectation that is in line with the findings of Trinh (2016); Mihaylova (2015); Salimi et al. (2014); Faustino and Vali (2011) and MacDonald and Majeed (2010). These studies confirm that rising inflation reduces real wages and disproportionately affects those in the bottom part of the income distribution, hence leading to high inequality. This is because inflation reduces a country's purchasing power and also hurts the poor more than the rich (Easterly \& Fischer, 2001). Whereas, the negative impact in Indonesia could be attributed to the fact that, high inflation rate adds to economic growth by encouraging investment and employment opportunities because it serves as a source of increasing revenues to investors. This is based on the fact that the rich can pursue several investment options in order not to be affected by the negative effects of inflation. 
Relatedly, the level of corruption in Nigeria and Turkey show a negative relationship with inequality, while it shows a positive relationship with inequality in Mexico and Indonesia. The implication is that in Nigeria and Turkey, an increase in the level of corruption will reduce inequality. The inverse association is premised on the fact that corruption can cause higher economic growth if those resources gained by the public officers are used for public gains and this seems to also follow "second-best theory" that states that corruption would allow people to avoid regulations that can hinder their investment opportunities, thus enabling them to create more jobs that will help in reducing inequality (Huntington, 1968; Leff, 1964). This is not the case in Mexico and Indonesia where public officers always take the resources gained out of the country. In such a situation, corruption will add to inequality. In analysing the joint effects of globalisation in respect of levels of economic growth and education in Table 4, the findings show that there is no evidence of Kuznets' hypothesis of an inverted U-shaped association between economic growth and income inequality in all the MINT countries, except in Indonesia where the hypothesis is accepted. However, there is Kuznets' evidence of a positive relationship between inequality and level of economic growth only in Turkey (Faustino \& Vali, 2011). The impact of overall globalisation on inequality is found to be positive and significant at 5 per cent in Mexico, Nigeria, and Turkey, while the impact is significantly negative at 5 per cent also in Indonesia. The positive relationship, which is in accordance with the studies of Dorn et al. (2017); Mahesh (2016); Kutor (2014); Atif et al. (2012); Dreher and Gaston (2008) and Kahai and Simmons (2005) could be as a result of relative factor endowments and level of protections put in place. The negative impact, which is in tandem with the studies of Salimi et al. (2014) and Zhou et al. (2011) in Indonesia could be as a result of open economic policy and the favorable socio-political climate of Indonesia.

An interesting result is found for the level of education while using overall globalisation index in Table 4 when compared with the various dimensions of globalisation in Table 3. Improved level of education implies that income inequality would fall in all the MINT countries, except in Turkey where inequality would continue to rise as the level of education improves at 5 per cent level of significance. Meanwhile, the impact is observed to be statistically insignificant in Mexico only (Asteriou et al., 2014). This shows that Indonesia and Nigeria will experience a lower level of inequality due to the higher level of education and also when all the dimensions of globalisation are pooled together as an overall globalisation index. This negative result is consistent with the studies of Bukhari and Munir (2016); Trinh (2016); Ucal et al. (2015) and MacDonald and Majeed (2010) while the positive impact is against the a priori expectation. Theoretically, the expectation is that human capital should reduce inequality but when faced with other challenges then it will show otherwise and this might be the case for Turkey. For instance, in Turkey, there are challenges (such as lack of infrastructures, shortage of teachers and schools, low teacher quality and inadequate funding) militating against the development of human capital (Erdem, Aydin, Tasdan, \& Akin, 2011).

Also, an increase in population growth follows the a priori expectation by increasing income inequality in Mexico and Turkey at 5 per cent significant level and the result shows otherwise in Indonesia (significant at 5 per cent level) and Nigeria (insignificant). This means that in Mexico and Turkey, a high population slows down the prospects for a better life for those already born by preventing the government to use her limited resources to provide basic amenities, hence increased inequality. This is consistent with the studies of Trinh (2016) and MacDonald and Majeed (2010). Inequality tends to reduce due to the increase in population (see (Amjad, 2015; Ucal et al., 2015)) in Indonesia. This is because there are an abundant labour pool and a very large domestic market for all types of manufactured goods and services that can fuel economic growth and attract more investment opportunities, leading to an increase in income-earning opportunities.

The impact of inflation is found to be significant at the 5 per cent level in all the MINT countries, except in Mexico. In Indonesia, a persistent rise in the prices of goods and services would amount to a lower level of inequality and this is against the theoretical expectation. On the other hand, the relationship between inflation and inequality in Nigeria and Turkey follows the a priori expectation and this is said to be in line with the studies of Trinh (2016); Mihaylova (2015) and Salimi et al. (2014). Thus, inflation in both countries widens the gap between the rich and the poor because it can reduce the purchasing power of their currencies. Also, the negative impact of inflation on the poor is pronounced when an increase in price level does not change the wage level. This is because trade unions are weak and minimum wage laws fail to work properly, especially in Nigeria.

A cursory look at the control of corruption in all the MINT countries reveals that an increase in corruption control (that is, a lower level of corruption) would reduce inequality in Mexico and Indonesia, and increase inequality in Nigeria and Turkey. The reason is not far-fetched as Nigerian and Turkish governments have been able to use the resources gained illegitimately for public gains, while in Mexico and Indonesia, a high level of corruption hinders investment opportunities, thus increased the level of inequality.

Specifically, the joint effect of overall globalisation and level of growth is found to reduce income inequality in all the MINT countries, except in Indonesia where its impact is positive, all at a 5 per cent level of significance see Table 4. This indicates that the level of growth has a lot to do in reducing inequality as globalisation alone might not be able to reduce the level of income inequality (Mihaylova, 2015; Salimi et al., 2014). For instance, Mexico sharing border with the United States has been able to improve her integration with other parts of the world including her level of economic growth which will help in reducing inequality. While in Nigeria, globalisation with economic growth help in creating trade, investment and job opportunities, increasing specialization and efficiency, transferring technology, and developing human resource, thus reducing inequality. Turkey is not left out as her level of globalisation along with economic growth plays an important role in reducing inequality as a result of her economic and social development performance, leading to increased employment and income-earning opportunities. Contrarily, the interactive term of globalisation and level of growth does not reduce inequality in Indonesia, as expected, and this is because the country is recently experiencing an economic slowdown with the same growth rate of GDPPC since 2017. The above results show that overall globalisation and level of growth are substitute and should be pursued differently to experience a low level of income inequality in all the MINT countries, except in Indonesia where the two variables are complementary and should be pursued simultaneously to achieve a low level of income inequality. Finally, a positive relationship is established between the joint effect of overall globalisation and the level of education and income inequality in Indonesia and Nigeria as shown in Table 4. The positive impact in Nigeria could be attributed to the fact that the positive impact of globalisation is more than the 
negative impact of human capital, while there is a problem of how to standardize education in Indonesia. The joint effect is negative in Mexico (but not significant) and Turkey and this follows some studies like Mihaylova (2015) and MacDonald and Majeed (2010) which argue that globalisation with the help of high level of education would go a long way in reducing inequality as it will provide income-earning opportunities for those with a higher level of education. Another inference from these results is that overall globalisation and level of education are complementary and should be used together to reduce income inequality in Indonesia and Nigeria, while the two variables are substitute in Mexico and Turkey, and should be pursued differently to experience a low level of income inequality.

Table-3. Kuznets' hypothesis, dimensions of globalisation, and income inequality in Mexico, Indonesia, Nigeria, and Turkey (1980-2018).

\begin{tabular}{|c|c|c|c|c|}
\hline \multirow[t]{2}{*}{ Exogenous Variable } & \multicolumn{4}{|c|}{ Endogenous Variable: YINQ } \\
\hline & Mexico & Indonesia & Nigeria & Turkey \\
\hline$\overline{Y I N Q(-1)}$ & $\begin{array}{c}0.75^{* *} \\
(0.00) \\
\end{array}$ & $\begin{array}{c}0.88^{* * *} \\
(0.00)\end{array}$ & $\begin{array}{c}0.98^{* *} \\
(0.00) \\
\end{array}$ & $\begin{array}{c}0.76^{* * *} \\
(0.00)\end{array}$ \\
\hline EGB & $\begin{array}{c}0.03^{* * *} \\
(0.00) \\
\end{array}$ & $\begin{array}{l}-0.01 \\
(0.13) \\
\end{array}$ & $\begin{array}{c}-0.0004 \\
(0.87) \\
\end{array}$ & $\begin{array}{l}0.02^{*} \\
(0.09)\end{array}$ \\
\hline SGB & $\begin{array}{c}0.05^{* * *} \\
(0.00)\end{array}$ & $\begin{array}{c}0.05^{* *} \\
(0.00)\end{array}$ & $\begin{array}{c}0.01 * * \\
(0.00)\end{array}$ & $\begin{array}{c}-0.06^{* *} * \\
(0.00)\end{array}$ \\
\hline PGB & $\begin{array}{l}\text { O.01* } \\
(0.09)\end{array}$ & $\begin{array}{c}0.01 \\
(0.77)\end{array}$ & $\begin{array}{c}-0.02^{*} * \\
(0.01)\end{array}$ & $\begin{array}{c}-0.02 * * \\
(0.03)\end{array}$ \\
\hline GDPPC & $\begin{array}{c}0.13^{* *} \\
(0.02) \\
\end{array}$ & $\begin{array}{c}0.49^{* *} \\
(0.00)\end{array}$ & $\begin{array}{l}0.35^{* *} \\
(0.01) \\
\end{array}$ & $\begin{array}{l}1.33^{* *} * \\
(0.00)\end{array}$ \\
\hline $\mathrm{GDPPC}^{2}$ & $\begin{array}{c}-0.10^{* * *} \\
(0.01) \\
\end{array}$ & $\begin{array}{c}-0.03^{* * *} \\
(0.01) \\
\end{array}$ & $\begin{array}{c}-0.02^{* * *} \\
(0.01) \\
\end{array}$ & $\begin{array}{c}-0.07^{* *} \\
(0.00) \\
\end{array}$ \\
\hline HUMC & $\begin{array}{c}-0.11^{*} * \\
(0.00)\end{array}$ & $\begin{array}{c}0.01 \\
(0.31)\end{array}$ & $\begin{array}{c}0.01 * * \\
(0.00)\end{array}$ & $\begin{array}{c}0.02^{* *} * \\
(0.00)\end{array}$ \\
\hline POP & $\begin{array}{c}0.03^{* *} \\
(0.00)\end{array}$ & $\begin{array}{c}0.11^{* *} \\
(0.00)\end{array}$ & $\begin{array}{c}-0.06^{* *} * \\
(0.04)\end{array}$ & $\begin{array}{c}0.02^{* *} * \\
(0.00)\end{array}$ \\
\hline INF & $\begin{array}{c}0.001 * * \\
(0.00)\end{array}$ & $\begin{array}{c}-0.002 * * \\
(0.00) \\
\end{array}$ & $\begin{array}{c}0.001^{* *} * \\
(0.00)\end{array}$ & $\begin{array}{l}0.01 * * \\
(0.00)\end{array}$ \\
\hline $\mathrm{COR}$ & $\begin{array}{c}-0.01^{*} \\
(0.01) \\
\end{array}$ & $\begin{array}{r}-0.001 \\
(0.58) \\
\end{array}$ & $\begin{array}{c}0.02^{* *} \\
(0.00)\end{array}$ & $\begin{array}{l}0.01 * * \\
(0.00)\end{array}$ \\
\hline Inst. Rank & 36 & 31 & 31 & 37 \\
\hline $\begin{array}{l}\text { J-Stat. } \\
\text { (Prob.) }\end{array}$ & $\begin{array}{c}8.90 \\
(0.89)\end{array}$ & $\begin{array}{c}8.34 \\
(0.88)\end{array}$ & $\begin{array}{c}8.15 \\
(0.89)\end{array}$ & $\begin{array}{c}9.27 \\
(0.95)\end{array}$ \\
\hline $\mathrm{AR}(1)$ & $(0.08)^{*}$ & $(0.50)$ & $(0.01)^{* *}$ & $(0.00)^{* * *}$ \\
\hline $\operatorname{AR}(2)$ & $(0.48)$ & $(0.34)$ & $(0.70)$ & $(0.18)$ \\
\hline Obs. & 35 & 30 & 36 & 35 \\
\hline
\end{tabular}

Note: ** and * represent 5 per cent and 10 per cent levels of significance, respectively.

Intercept values are not reported.

P-values are reported in parentheses.

Table-4. Kuznets' hypothesis, overall globalisation, and income Inequality in Mexico, Indonesia, Nigeria, and Turkey (1980-2018).

\begin{tabular}{|c|c|c|c|c|}
\hline \multirow[t]{2}{*}{$\overline{\text { Exogenous Variable }}$} & \multicolumn{4}{|c|}{ Endogenous Variable: YINQ } \\
\hline & Mexico & Indonesia & Nigeria & Turkey \\
\hline YINQ(-1) & $\begin{array}{c}0.74^{* * *} \\
(0.00)\end{array}$ & $\begin{array}{c}0.96^{* * *} \\
(0.00)\end{array}$ & $\begin{array}{c}0.86^{* * *} \\
(0.00)\end{array}$ & $\begin{array}{c}0.68^{* * *} \\
(0.00)\end{array}$ \\
\hline GBI & $\begin{array}{c}2.49^{* *} \\
(0.00)\end{array}$ & $\begin{array}{c}-3.38^{* *} \\
(0.00)\end{array}$ & $\begin{array}{c}0.36^{* * *} \\
(0.04)\end{array}$ & $\begin{array}{c}4.00^{* * *} \\
(0.00)\end{array}$ \\
\hline GDPPC & $\begin{array}{c}-3.09^{* * *} \\
(0.01)\end{array}$ & $\begin{array}{c}2.67^{* *} * \\
(0.00)\end{array}$ & $\begin{array}{l}-0.04 \\
(0.42)\end{array}$ & $\begin{array}{c}0.33^{* * *} \\
(0.00)\end{array}$ \\
\hline $\mathrm{GDPPC}^{2}$ & $\begin{array}{c}0.23^{*} * \\
(0.01)\end{array}$ & $\begin{array}{c}-0.23^{* *} \\
(0.00)\end{array}$ & $\begin{array}{c}0.01^{* *} * \\
(0.03)\end{array}$ & $\begin{array}{c}0.07 * * \\
(0.00)\end{array}$ \\
\hline HUMC & $\begin{array}{c}0.10 \\
(0.44)\end{array}$ & $\begin{array}{c}-1.43^{* *} \\
(0.00)\end{array}$ & $\begin{array}{c}-0.22^{* *} \\
(0.00)\end{array}$ & $\begin{array}{c}0.44^{*} * \\
(0.00)\end{array}$ \\
\hline POP & $\begin{array}{c}0.03^{* *} \\
(0.00)\end{array}$ & $\begin{array}{c}-0.11^{* *} \\
(0.01)\end{array}$ & $\begin{array}{l}-0.01 \\
(0.55)\end{array}$ & $\begin{array}{c}0.02^{* *} \\
(0.00)\end{array}$ \\
\hline INF & $\begin{array}{c}0.0001 \\
(0.69)\end{array}$ & $\begin{array}{c}-0.003^{* *} \\
(0.00)\end{array}$ & $\begin{array}{c}0.001^{*} * \\
(0.00)\end{array}$ & $\begin{array}{c}0.003^{* *} * \\
(0.00)\end{array}$ \\
\hline COR & $\begin{array}{c}-0.01 * * \\
(0.00)\end{array}$ & $\begin{array}{c}-0.003^{* *} \\
(0.00)\end{array}$ & $\begin{array}{c}0.02^{* *} \\
(0.00)\end{array}$ & $\begin{array}{c}0.01 * * \\
(0.00)\end{array}$ \\
\hline GBI*GDPPC & $\begin{array}{c}-0.25^{* *} \\
(0.03)\end{array}$ & $\begin{array}{l}0.24^{* *} \\
(0.00)\end{array}$ & $\begin{array}{c}-0.06^{* *} \\
(0.02)\end{array}$ & $\begin{array}{c}-0.40^{* *} * \\
(0.00)\end{array}$ \\
\hline GBI*HUMC & $\begin{array}{l}-0.04 \\
(0.21)\end{array}$ & $\begin{array}{c}0.36^{* *} \\
(0.00)\end{array}$ & $\begin{array}{c}0.06 * * \\
(0.00)\end{array}$ & $\begin{array}{c}-0.11^{* * *} \\
(0.00)\end{array}$ \\
\hline Inst. Rank & 34 & 29 & 35 & 36 \\
\hline $\begin{array}{l}\text { J-Stat. } \\
\text { (Prob.) }\end{array}$ & $\begin{array}{c}8.91 \\
(0.89)\end{array}$ & $\begin{array}{c}6.86 \\
(0.89)\end{array}$ & $\begin{array}{c}8.88 \\
(0.90)\end{array}$ & $\begin{array}{c}8.73 \\
(0.89)\end{array}$ \\
\hline $\mathrm{AR}(1)$ & $(0.04)^{* * *}$ & $(0.04)^{* *}$ & $(0.00)^{* *}$ & $(0.00)^{* *}$ \\
\hline $\operatorname{AR}(2)$ & $(0.19)$ & $(0.17)$ & $(0.48)$ & $(0.40)$ \\
\hline Obs. & 36 & 28 & 35 & 35 \\
\hline
\end{tabular}

Note: ** and * represent 5 per cent and 10 per cent levels of significance, respectively.

Intercept values are not reported.

$\mathrm{P}$-values are reported in parentheses. 


\section{Concluding Remarks}

The study tests for the validity of Kuznets' hypothesis and examines the relative effects of the dimensions of globalisation and overall globalisation on income inequality between 1980 and 2018. The dynamic GMM results show that all the various dimensions of globalisation were important for Kuznets' hypothesis to be accepted in all the MINT countries. This is because while using overall globalisation, there is no evidence of Kuznets' hypothesis in all the MINT countries, except in Indonesia.

In Mexico, all the dimensions of globalisation including overall globalisation increases income inequality. Human capital with the various dimensions of globalisation increases income inequality, while with overall globalisation its effect is insignificant. Population growth increases inequality, while the effect of inflation rate on inequality is positive with the various dimensions of globalisation and its effect is insignificant with overall globalisation. Also, a high level of corruption increases income inequality in Mexico. The joint effect of Globalisation and economic growth reduces economic growth, while that of globalisation and the level of education is insignificant.

The impacts of economic and political globalisation are insignificant in Indonesia. Meanwhile, social and overall globalisation increases and reduces income inequality, respectively. Human capital, with the various dimensions of globalisation, insignificantly affects income inequality, while with overall globalisation its effect is negative, as expected. With the various dimensions of globalisation, an increase in population increases inequality, while with the overall globalisation, an increase in population reduces income inequality. Inflation and the level of corruption reduce income inequality in Indonesia. The joint effects of globalisation and each of economic growth and level of education increase income inequality in Indonesia.

In examining the Nigerian economy, economic globalisation has a non-significant effect on income inequality, political globalisation reduces income inequality, and social globalisation and overall globalisation add to income inequality. With the various dimensions of globalisation, a high level of education increases income inequality, while with the overall globalisation, the effect of education on inequality is inverse. Population growth reduces inequality with the various dimensions of globalisation but its effect is insignificant with overall globalisation. Inflation and the level of corruption increases and reduces income inequality, respectively. The conditional effects of globalisation and each of economic growth and level of education reduces and increases income inequality, respectively.

To end this, an increase in each of economic and overall globalisation increases income inequality, while social and political globalisation in Turkey cause inequality to reduce. Human capital, population growth, and inflation increase income inequality, while the level of corruption, the joint effects of globalisation and each economic growth and level of education reduce income inequality in Turkey.

It is recommended that all the MINT countries need to put in place measures, such as economic, social, and political stability that will enable them to benefit from the globalisation process as these benefits might help in reducing income inequality. The government of the MINT countries should not attach so much importance to certificates in accessing any job opportunity, especially in Mexico and Nigeria. However, human capital in all the MINT countries can be improved through adequate investment in education to reduce income inequality. Population growth should be reduced in all the MINT countries in order not to limit the government resources in providing a better life for those already born. Meanwhile, the Nigerian government can achieve a high level of growth that can help in reducing inequality if they channel their high population towards improved productivity. Also, if the resources in the Nigerian economy are properly managed, then population growth should not add to income inequality.

Furthermore, the rate of inflation needs to be moderate and stable through such measures as a reduction in money supply, reduction in the budget deficit, total ban on the importation of certain items, especially when inflation is imported, and increase in the production of goods and services. Specifically, the inflation rate in Indonesia should be tied to the wage level since income inequality reduces as inflation rises. There is a need for transparency and accountability in government functions in MINT countries, particularly in financial transactions. This can improve the level of globalisation, reduce inequality in each of the MINT countries. Precisely, a high level of corruption is observed to reduce income inequality in Nigeria. If this is the case, there should be a way to see that the resources gained illegitimately are used for public gains in terms of investment and income-earning opportunities to income inequality.

Finally, other studies can examine the joint effect of each of the dimensions of globalisation with the levels of education and economic growth on income inequality as against the joint effects of overall globalisation with the levels of education and economic growth that this present study examines. In addition, future research can test for the validity of Kuznets' hypothesis in other groups of countries such as BRICS, Next 11, and NICs.

\section{References}

Agusalim, L., \& Pohan, F. S. (2018). Trade openness effect on income inequality: Empirical evidence from Indonesia. Significant: Journal of Economics, 7(1), 1-14.Available at: https://doi.org/10.15408/sjie.v7i1.5527.

Alderson, A. S., \& Nielsen, F. (1999). Income inequality, development, and dependence: A reconsideration. American Sociological Reviere, 64(4), 606-616.Available at: https://doi.org/10.2307/2657259.

Alderson, A. S., \& Nielsen, F. (2002). Globalization and the great U-turn: Income inequality trends in 16 OECD countries. American Journal of Sociology, 107(5), 1244-1299.Available at: https://doi.org/10.1086/341329.

Amjad, Z. (2015). Trade and income distribution in Pakistan. Global Journal of Management and Business Research: Economics and Commerce, $15(8), 18-25$.

Asteriou, D., Dimelis, S., \& Moudatsou, A. (2014). Globalization and income inequality: A panel data econometric approach for the EU27 countries. Economic Modelling, 36(C), 592-599.

Atif, M., Srivastav, M., Sauytbekova, M., \& Arachchige, K. (2012). Globalization and income inequality: A panel data analysis of 68 countries. Munich Personal RePec Archive Paper No. 42385.

Babatunde, M. A. (2018). FDI and income inequality in Nigeria. International Journal of Economic Development, 11(2), 266-315.

Baek, I., \& Shi, Q. (2016). Impact of economic globalization on income inequality: Developed economies vs emerging economies. Global Economy Journal, 16(1), 49-61.Available at: https://doi.org/10.1515/gej-2015-0047.

Baiardi, D., \& Morana, C. (2018). Financial development and income distribution inequality in the euro area. Economic Modelling, 70, 4055.Available at: https://doi.org/10.1016/j.econmod.2017.10.008. 
Basu, P., \& Guariglia, A. (2007). Foreign direct investment, inequality, and growth. Journal of Macroeconomics, 29(4), 824-839.

Beer, L., \& Boswell, T. (2002). The resilience of dependency effects in explaining income inequality in the global economy: A cross national analysis, 1975-1995. Journal of World-Systems Research, 8(1), 30-59.

Bergh, A., \& Nilsson, T. (2010). Do liberalization and globalization increase income inequality? European Journal of Political Economy, 26(4), 488-505.Available at: https://doi.org/10.1016/j.ejpoleco.2010.03.002.

Bhandari, B. (2007). Effect of inward foreign direct investment on income inequality in transition countries. Journal of Economic Integration, 22(4), 888-928.Available at: https://doi.org/10.11130/jei.2007.22.4.888.

Blinder, A. S. (2006). Offshoring: The next industrial revolution. Foreign Affairs, 85(2), 113-128.Available at: https://doi.org/10.2307/20031915.

Bond, S., Hoeffler, A., \& Temple, J. (2001). GMM estimation of empirical growth models. Economic Papers, W21. Nuffield College, University of Oxford, United Kingdom.

Borraz, F., \& Lopez-Cordova, J. E. (2007). Has globalization deepened income inequality in Mexico? Global Economy Journal, 7(1), 1850103.Available at: https://doi.org/10.2202/1524-5861.1237.

Bukhari, M., \& Munir, K. (2016). Impact of globalization on income inequality in selected Asian countries. MPRA Paper, No. 74248.

Cabral, R., García-Díaz, R., \& Mollick, A. V. (2016). Does globalization affect top income inequality? Journal of Policy Modeling, 38(5), 916940.Available at: https://doi.org/10.1016/j.jpolmod.2016.05.001.

Celik, S., \& Basdas, U. (2010). How does globalization affect income inequality? A panel data analysis. International Advances in Economic Research, 16(4), 358-370.Available at: https://doi.org/10.1007/s11294-010-9281-0.

Chintrakarn, P., Herzer, D., \& Nunnenkamp, P. (2010). FDI and income inequality: Evidence from a panel of US States. Kiel Institute for the World Economy, Kiel Working Paper No. 1579.

Choi, C. (2006). Does foreign direct investment affect domestic income inequality? Applied Economics Letters, 13(12), 811-814.Available at: https://doi.org/10.1080/13504850500400637.

David, M. S. (2011). Globalization and income inequality in Brazil. Master's Thesis, Aarhus School of Business, Aarhus University, Denmark.

De Haan, J., \& Sturm, J.-E. (2017). Finance and income inequality: A review and new evidence. European Journal of Political Economy, 5o(C), $171-195$.

Deng, W.-S., \& Lin, Y.-C. (2013). Parameter heterogeneity in the foreign direct investment-income inequality relationship: A semiparametric regression analysis. Empirical Economics, 45(2), 845-872.

Dollar, D., \& Kraay, A. (2002). Growth is good for the poor. Journal of Economic Growth, 7(3), 195-225.

Dorn, F., Fuest, C., \& Potrafke, N. (2017). Globalisation and income inequality revisited. European Economy Discussion Paper No. O56.

Dreher, A. (2006). Does globalization affect growth? Evidence from a new index of globalization. Applied Economics, 38(10), 109111 10.Available at: https://doi.org/10.1080/00036840500392078.

Dreher, A., \& Gaston, N. (2008). Has globalization increased inequality? Review of International Economics, 16(3), 516-536.Available at: https://doi.org/10.1111/j.1467-9396.2008.00743.x.

Dreher., A., Gaston, N., \& Martens, P. (2008). Measuring globalisation - gauging its consequences. Berlin, Germany: Springer.

Easterly, W., \& Fischer, S. (2001). Inflation and the poor. Journal of Money, Credit and Banking, 33(2), 160-178.

Erdem, M., Aydin, I., Tasdan, M., \& Akin, U. (2011). Educational problems and solutions in Turkey: The views of district governors. Educational Management Administration \& Leadership, 39(2), 242-256.Available at: https://doi.org/10.1177/1741143210390059.

Fafowora, O. O. (1998). Management imperatives of globalization management in Nigeria. Journal of Nigeria Institute of Management, 34(2-4), $5-9$.

Farhan, M., Azman-Saini, W., \& Law, S. (2014). FDI and income inequality in ASEAN-5 countries: A quantile regression approach. Prosidin Pier KEM, 9(2014), 601-608.

Faustino, H., \& Vali, C. (2011). The effects of globalization on OECD income inequality: A static and dynamic analysis. Technical University of Lisbon, School of Economics and Management, Department of Economics Working Paper No. 12/2011/DE.

Feenstra, R. C., \& Hanson, G. H. (1997). Foreign direct investment and relative wages: Evidence from Mexico's maquiladoras. Journal of International Economics, 42(3-4), 371-393.Available at: https://doi.org/10.1016/s0022-1996(96)01475-4.

Figini, P., \& Gorg, H. (2011). Does foreign direct investment affect wage inequality? An empirical investigation. The World Economy, 34(9), 1455-1475.Available at: https://doi.org/10.1111/j.1467-9701.2011.01397.x.

Halmos, K. (2011). The effect of FDI, exports and GDP on income inequality in 15 Eastern European countries. Acta Polytechnica Hungarica, $8(1), 123-136$.

Harrison, A., \& Hanson, G. (1999). Who gains from trade reform? Some remaining puzzles. Journal of Development Economics, 59(1), 125154.Available at: https://doi.org/10.1016/s0304-3878(99)00008-5.

Hassan, O. M. (2013). An appraisal of the effects of globalization on the Nigerian economy. American Journal of Business and Management, 2(4), 296-303.

Heckscher, E. (1919). The effect of foreign trade on the distribution of income. Economic Journal, 21(1919), 497-512.

Herzer, D., Hühne, P., \& Nunnenkamp, P. (2014). FDI and income inequality -evidence from Latin American economies. Review of Development Economics, 18(4), 778-793.Available at: https://doi.org/10.1111/rode.12118.

Herzer, D., \& Nunnenkamp, P. P. (2011). FDI and income inequality: Evidence from Europe. Kiel Institute for the World Economy Working Paper, No. 1675 .

Herzer, D., \& Nunnenkamp, P. P. (2012). The effect of foreign aid on income inequality: Evidence from panel cointegration. Kiel Working Paper, No. 1762, Kiel Institute for the World Economy, Hindenburgufer 66, 24105 Kiel, Germany.

Herzer., D., \& Nunnenkamp, P. (2013). Inward and outward FDI and income inequality: Evidence from Europe. Review of World Economics, 149(2), 395-422.Available at: https://doi.org/10.1007/s 10290-013-0148-3.

Huntington, S. P. (1968). Political order in changing societies. Yale University Press: New Haven and London.

ICRG. (2018). International country risk guide dataset. East Syracuse, New York, United States: The PRS Group, Inc.

Im, H., \& McLaren, J. (2015). Does foreign direct investment raise income inequality in developing countries? A new instrumental variables approach. school of economics and finance. South Korea: Yeungnam University.

Jaumotte, F., Lall, S., \& Papageorgiou, C. (2013). Rising income inequality: Technology, or trade and financial globalization? IMF Economic Review, 61(2), 271-309.Available at: https://doi.org/10.1057/imfer.2013.7.

Jensen, N. M., \& Rosas, G. (2007). Foreign direct investment and income inequality in Mexico, 1990-2000. International Organization, 61(3), 467-487.Available at: https://doi.org/10.1017/s0020818307070178.

Kahai, S. K., \& Simmons, W. (2005). The impact of globalisation on income inequality. Global Business and Economics Review, 7(1), 115.Available at: https://doi.org/10.1504/gber.2005.006915.

KOF. (2018). The KOF globalization index. Swiss Economic Institute. Retrieved from: www.kof.ethz.ch. [Accessed 2019-03-15].

Kratou, H., \& Goaied, M. (2016). How can globalization affect income distribution? Evidence from developing countries. The International Trade Journal, 30(2), 132-158.Available at: https://doi.org/10.1080/08853908.2016.1 139480.

Krugman, P. R. (2008). Trade and wages, reconsidered. Brookings Papers on Economic Activity, 2008(1), 103-154.Available at: https://doi.org/10.1353/eca.0.0006.

Kutor, S. K. (2014). Processes of globalization and its effects on the life of people in the global South by drawing examples from Ghana. Research on Humanities and Social Sciences, 4(6), 95-99.

Kuznets, S. (1955). Economic growth and income inequality. The American Economic Revierw, 45(1), 1-28.

Lee, K.-K. (2014). Globalization, income inequality and poverty: Theory and empirics. Social System Studies, 28(3), 109-134.

Leff, N. H. (1964). Economic development through bureaucratic corruption. American Behavioral Scientist, 8(3), 8-14.Available at: https://doi.org/10.1177/000276426400800303.

Lim, G., \& McNelis, P. D. (2016). Income growth and inequality: The threshold effects of trade and financial openness. Economic Modelling, 58, 403-412.Available at: https://doi.org/10.1016/j.econmod.2016.05.010. 
Lipsey, R. E., \& Sjoholm, F. (2001). Foreign direct investment and wages in Indonesian manufacturing. National Bureau of Economic Research (NBER) Working Paper, No. 8299.

Liu, G., Liu, Y., \& Zhang, C. (2016). Financial development, financial structure and income inequality in China. The World Economy, 4O(9), 128.

MacDonald, R., \& Majeed, M. T. (2010). Distributional and poverty consequences of globalization: A dynamic comparative analysis for developing countries. Scottish Institute for Research in Economics (SIRE) Discussion Paper, No. SIRE-DP-2010-62.

Mah, J. S. (2002). The impact of globalization on income distribution: The Korean experience. Applied Economics Letters, 9(15), 10071009.Available at: https://doi.org/10.1080/13504850210149124.

Mah, J. S. (2003). A note on globalization and income distribution-the case of Korea, 1975-1995. Journal of Asian Economics, 14(1), 157164.Available at: https://doi.org/10.1016/s1049-0078(02)00244-0.

Mahesh, M. (2016). The effects of trade openness on income inequality-evidence from BRIC countries. Economics Bulletin, 36(3), $1751-1761$.

Marjit, S., Beladi, H., \& Chakrabarti, A. (2004). Trade and wage inequality in developing countries. Economic Inquiry, 42(2), 295-303.Available at: https://doi.org/10.1093/ei/cbho61.

Matsangou, E. (2015). Is MINT the next BRIC? Online article Retrieved from: https://www.theneweconomy.com/business/is-mint-thenext-bric.

Mihaylova, S. (2015). Foreign direct investment and income inequality in central and Eastern Europe. Theoretical and Applied Economics, $22(2), 23-42$.

Milanovic, B. (2005). Can we discern the effect of globalization on income distribution? Evidence from household surveys. The World Bank Economic Review, 19(1), 21-44.Available at: https://doi.org/10.1093/wber/lhioo3.

Mills, M. (2009). Globalization and inequality. European Sociological Review, 25(1), 1-8.

Msweli, P. (2015). The effect of foreign direct investment on inequality: The case of South Africa. Master's Thesis, Stellenbosch University, South Africa.

Mugeni, S. (2015). Foreign investment, democracy and income inequality: Empirical evidence. Master's Thesis, Department of Economics, University of Ottawa, U.S.A.

Nguyen, Q. (2017). Mind the gap? Rising income inequality and individual trade policy preferences. European Journal of political economy, 50, 92-105.Available at: https://doi.org/10.1016/j.ejpoleco.2017.07.006.

Nunnenkamp, P., Schweickert, R., \& Wiebelt, M. (2007). Distributional effects of FDI: How the interaction of FDI and economic policy affects poor households in Bolivia. Development Policy Review, 25(4), 429-450.Available at: https://doi.org/10.1111/j.14677679.2007.00379.x.

Ogunyomi, O. O., Daisi, O. R., \& Oluwashikemi, R. A. (2013). Economic globalization, income inequality and economic growth in Nigeria: A static data analysis (1986-2010). ABC Journal of Advanced Research, 2(2), 55-68.Available at: https://doi.org/10.18034/abcjar.v2i2.25.

Ohlin, B. (1933). Interregional and international trade. Cambridge, MA, United Kingdom: Harvard University Press.

Okatan, N. G. (2011). How does globalization affect income inequality among developing countries? Master's Thesis, Department of Economics, Faculty of Economics and Business, Tilburg University, Netherlands.

Olomola, P. A., \& Osinubi, T. T. (2018). Determinants of total factor productivity in Mexico, Indonesia, Nigeria and Turkey (1980-2014). Emerging Economy Studies, 4(2), 192-2 17.Available at: https://doi.org/10.1177/2394901518795072.

Orga, J. I. (2012). Globalisation: The Nigerian experience. Review of Public Administration \& Management, 1(2), 154-179.Available at: https://doi.org/10.4172/2315-7844.1000109.

Reuveny, R., \& Li, Q. (2003). Economic openness, democracy, and income inequality: An empirical analysis. Comparative Political Studies, 36(5), 575-601.Available at: https://doi.org/10.1177/0010414003036005004.

Ricardo, D. (1817). On the principles of political economy and taxation. London: John Murray, Albemarle-Street.

Rye, S. J. (2016). FDI and its effect on income inequality. Master's Thesis, Economics Institute, University of Oslo, Norway.

Salimi, F., Akhoondzadeh, T., \& Arsalanbod, M. R. (2014). The triangle of trade liberalization, economic growth and income inequality. Communications on Advanced Computational Science with Applications, 26(1), 1-15.Available at: https://doi.org/10.5899/2014/cacsa00026.

Spilimbergo, A., Londoño, J. L., \& Székely, M. (1999). Income distribution, factor endowments, and trade openness. Journal of Development Economics, 59(1), 77-101.Available at: https://doi.org/10.1016/s0304-3878(99)00006-1.

Stiglitz, J. (2002). Globalization and its discontents. Penguin books Harmondsworth. UN general. New York: W. W. Norton.

Suanes, M. (2016). Foreign direct investment and income inequality in Latin America: A sectoral analysis. CEPAL Review, 118 (April), 45-61.

Summers, L. (2006). Reflections on global account imbalances and emerging markets reserve accumulation. Mumbai, India: L.K. Jha Memorial Lecture, Reserve Bank of India.

SWIID. (2018). Standardized world income inequality database. Retrieved from: https://doi.org/10.7910/DVN/WKOKHF, Harvard Dataverse, V20, United States.

Sylwester, K. (2005). Foreign direct investment, growth and income inequality in less developed countries. International Review of Applied Economics, 19(3), 289-300.Available at: https://doi.org/10.1080/02692170500119748.

Todaro, M. P., \& Smith, S. C. (2015). Economic development (12th ed.). United States: Pearson.

Transparency International's Corruption Perception Index. (2014). Transparency international: The global coalition against corruption database. Berlin, Germany: Transparency International's Corruption Perception Index.

Trinh, N. H. (2016). The effect of foreign direct investment on income inequality in Vietnam. International Journal of Economics, Commerce and Management, 4(12), 158-173.

Ucal, M., Bilgin, M. H., \& Haug, A. A. (2014). Income inequality and FDI: Evidence with Turkish data. Economics Discussion Papers, No. 1407, University of Otago.

Ucal, M., Haug, A. A., \& Bilgin, M. H. (2015). Income inequality and FDI: Evidence with Turkish data. Applied Economics, Taylor \& Francis Journals, $48(11), 1030-1045$.

Wade, R. H. (2004). Is globalization reducing poverty and inequality? International Journal of Health Services, 34(3), 381-414.Available at: https://doi.org/10.2190/g8f1-01fl-medw-jvg 1 .

WDI. (2018). World bank development indicators database. New York: Oxford University Press.

Williamson, J. G. (2015). Latin American inequality: Colonial origins, commodity booms or a missed twentieth-century leveling? Journal of Human Development and Capabilities, 16(3), 324-341.Available at: https://doi.org/10.1080/19452829.2015.1044821.

Wooldridge, J. M. (2001). Applications of generalized method of moments estimation. Journal of Economic perspectives, 15(4), 87-100.

Wu, J.-Y., \& Hsu, C.-C. (2012). Foreign direct investment and income inequality: Does the relationship vary with absorptive capacity? Economic Modelling, 29(6), 2183-2189.Available at: https://doi.org/10.1016/j.econmod.2012.06.013.

Zhang, X., \& Zhang, K. H. (2003). How does globalisation affect regional inequality within a developing country? Evidence from China. Journal of Development Studies, 39(4), 47-67.Available at: https://doi.org/10.1080/713869425.

Zhou, L., Biswas, B., Bowles, T., \& Saunders, P. J. (2011). Impact of globalization on income distribution inequality in 60 countries. Global Economy Journal, 1 1(1), 1-16.Available at: https://doi.org/10.2202/1524-5861.1628.

Zulfiu-Alili, M. (2014). Inward foreign direct investment and wage inequality in Macedonia. Eastern European Economics, 52(5), 5686.Available at: https://doi.org/10.1080/00128775.2014.1004265. 